REV. ROMAN BOGACZ

\title{
Second Vatican Council Fathers and Their Concern about Catholic Biblical Studies
}

The decision of Pope John XXIII to convoke the Second Vatican Council was made with care about the Church in heart. It was necessary to reform a number of aspects of Church life, such as liturgy and prayer, but it was also crucial to reform and alter theology, being the whole Catholic doctrine, and its approach to different fields of science. The Sacred Scripture is the foundation of theology. Despite different efforts that had been made since the proclamation of Pope Leo XIII Encyclical Providentissimus Deus (1893), the Catholic Biblical Studies were left behind the rapidly developing Protestant Biblical Studies. The following text is merely a summary of all the efforts of the Church that had to be made, in order for the Catholic Biblical Studies to meet the requirements that they were faced with. Apart from the documents of the Church prepared for various conciliar sessions, working on this article the author used two other books, both published in Polish: Sobór Watykański II a biblistyka katolicka by rev. Eugeniusz Dąbrowski ${ }^{1}$ and a collective work, published thanks to the efforts of the Polish Theological Society, entitled Idee przewodnie soborowej Konstytucji o Bożym Objawieniu. ${ }^{2}$

\footnotetext{
${ }^{1}$ E. Dąbrowski, Sobór Watykański II a biblistyka katolicka, Poznań-Warszawa-Lublin 1967.

${ }^{2}$ K. Wojtyła i inni, Idee przewodnie soborowej Konstytucji o Bożym Objawieniu, Kraków 1968.
} 


\section{Before the Council}

Fifty years after the Encyclical of Leo XIII was released, a difficult and tempestuous conflict concerning the Bible and natural sciences was taking place. Attempts were made to prove the Bible inerrant in all fields. The conflict was finally resolved by Pope Pius XII, who published the Encyclical Divino afflante Spiritu (1943) in which he clearly stated that the aim of the authors of the Bible, inspired by the Holy Spirit, was not presentation of natural science facts, but, most importantly, revelation of God and guiding people to salvation.

Before the Council biblicists had to face new problems that had arisen. The development of archaeology and new discoveries called for the confrontation if the history presented in the Bible, being the history of salvation, corresponds with data revealed by the archaeological discoveries made. The works in Jericho turned out to be problematic, as they proved that the city was destroyed in $15^{\text {th }}$ century B.C. In that case, when did the Israelites flee from Egypt? Does the order of events in the Bible comply with the history discovered by different scientific methods supporting history? In the attempt of solving the difficult historical issues, some exegetes, in their search for the truth, began to analyse the question of literary genres in the Sacred Books. It initially caused many objections among biblicists. ${ }^{3}$ Moreover, the application of the historical-critical method was strongly criticised. One Italian author claimed that the Sacred Scripture ought to be commented on in the form of mystically - pious deliberations. ${ }^{4}$ However, Pope Pius XII found his claims in opposition with the doctrine of the Catholic Church and ordered to put his work in the Index Librorum Prohibitorum. What is more, the Pontifical Biblical Commission was ordered to prepare a special letter addressed to Italian bishops, in which the Commission explained that the literal sense of the

${ }^{3}$ Cf. E. Dąbrowski, Sobór Watykański II a biblistyka katolicka, p. 49.

${ }^{4}$ Rev. Dolindo Ruotolo, under a pseudonim 'Daïn Cohenel', published a thirteenvolume commentary on the Sacred Scripture in which he criticised Catholic biblical schools, including the Pontifical Biblical Institute in Rome, accusing them of implementing harmful rationalism in the Catholic teachings. 
text of the Bible must first be determined, and only then is it possible to proceed with further mystical analysis. ${ }^{5}$ Two years later the Encyclical Divino afflante Spiritu was published, in which the Pope commanded the exegetes who knew the original languages of the Sacred Scripture and were working on explaining and commenting on the text of the Bible to focus on determining the literal meaning of the text, and then, to work on the theological content, teaching about the faith and tradition. He also urged them not to focus only on finding coherence between the biblical texts and natural science, history or philosophy.

After World War II the Pontifical Biblical Institute played an important role in Rome. It gathered outstanding biblicists and it became an important Catholic scholarly centre. However, among the Institute members heated discussions took place. One of them was provoked by an article prepared by L. Alonso Schökel, a professor of PBI, entitled: Dove va l'esegesi cattolica?. ${ }^{6}$ Answering the question posed in the title of the article: where is the Catholic exegesis going?, the author elaborated on the problem with great care. He showed that exegesis is fulfilling the commands of the Encyclical of Pius XII Divino afflante Spiritu. In his article, he included personal views and judgements of different authors working on biblical issues. It raised even greater controversy, especially among the more conservative authors, who were concerned about the Catholic faith and its stability, if Catholic exegesis were to follow the Protestant one. One of the opponents was Antonino Romeo, who stated that L. Alonso Schökel, M. Zerwick, S. Lyonet, J. Levi were making a number of exegetic mistakes, which by no means could comply with the Catholic faith. ${ }^{7}$ The objections against each of them were specified and stated clearly. E. Vogt commented on the matter on behalf of the Pontifical Biblical Institute. He explained A. Romeo's objections in a detailed manner. His presentation

${ }^{5}$ Pius XII, Litterae ad Archiepiscopos et Episcopos Italiae (20 August 1941), [in:] Enchiridion Biblicum. Documenti della Chiesa sulla Sacra Scrittura, Bologna 1993, no. 522-533.

${ }^{6}$ L. Alonso Schökel, Dove va l'esegesi cattolica, "La Civiltà Cattolica” 111 (1960), p. $449-460$.

${ }^{7}$ A. Romeo, L'Enciclica "Divino afflante Spiritu” e le “Opiniones Novae," Roma 1960. 
was supported by the representatives of the Pontifical Biblical Commission. Since the discussions were still taking place, the Pontifical Biblical Institute published an official response to allegations made. ${ }^{8}$ With an intention of terminating all discussions, the Congregation of the Holy Office published a general notice on 20 June $1961 .^{9}$ As a result, A. Romeo was silenced and stopped provoking discussions, a few months later, however, M. Zerwick and S. Lyonnet lost their right to lecture in PBI.

During the period directly preceding the Second Vatican Council, the question of co-ordinating all data concerning Jesus Christ that appeared in the Gospels was an important issue for Catholic Biblical Studies. In the hitherto Catholic exegesis the Gospels were treated strictly as chronicle writings, but there are discrepancies between some facts from Jesus' life, e.g. descriptions of His childhood and the Passion. Trying to apply new exegetical methods, the literary genres of particular fragments of the Bible were being analysed. Questions arose whether it was speech or rather written descriptions of events that had a more historical character. A detailed analysis of this problem seems like a fascinating task. It was, unfortunately, impossible to include a minute description of all disputes concerning this problem in this short article. ${ }^{10}$

\section{The Council and the Biblical Studies}

The controversies preceding the Second Vatican Council partly determined the issues that the Council Fathers had to take care of in order for the Catholic Biblical Studies to be able to face the challenges that rapidly

${ }^{8}$ Pontificium Institutum Biblicum et recens libellus R.mi D.ni A. Romeo, "Verbum Domini” 39 (1961), p. 3-17.

${ }^{9}$ Enchiridion Biblicum, no. 634.

${ }^{10}$ An example of an attempt to synchronise the events from the life of Jesus is a small publication by J. Steinmann, La vie de Jésus, Paris 1959. E. Dąbrowski is highly critical towards the methodology applied in this booklet; cf. E. Dąbrowski, Sobór Watykański II a biblistyka katolicka, p. 64-65. Nowadays both the booklet's content and the methodology used would probably be more easily accepted. 
developing science had posed. The problem of the Bible versus natural science, history, and rapidly developing archaeology had to be addressed and solved. The problem of the historical accuracy of data included in the Gospels was an important issue. Another thing was the analysis of the process of writing the Gospels, as well as the Old Testament Books. Catholic biblicists were still unable to apply research data on biblical literary genres to their biblical texts analysis. In their analyses they were often restricted by authoritarian commands of Church authorities.

\subsection{Disputes and controversies}

Cardinal E. Ruffini, ${ }^{11}$ only days before the Council, published a conservative article in which he criticised the efforts of biblicists based on the attempt to apply literary genres to research on historical biblical books. The criticised biblicists were the ones trying to separate in biblical texts historical data from the narrative, in which the details presented are often inconsistent with historical research.

In the presence of huge criticism of the Protestant exegesis concerning historicity of the Bible, Cardinal A. Bea published a memorial on: L'historicité des Evangiles. The aim of this publication was providing the Council Fathers with pastoral material which could be taken into consideration during their proceedings. In his text, cardinal A. Bea criticised the method of the history of form, established by the Protestant circles for the analysis of the Gospels. He also discussed the issue of historical accuracy of the Gospel, especially the credibility of Jesus' words quoted in the Bible (ipsissima verba Jesu). In his work he does not rule out that some statements and expressions might have been modified. In his text, the author seems very careful while formulating opinions, although he clearly states that this broader perception of the quoted words of Jesus does not exclude the truth of biblical inspiration that the Books were written under.

${ }^{11}$ E. Ruffini, Generi letterari e ipotesi di lavoro nei recenti studi biblici, „L'Osservatore Romano," 24 VIII 1961. 
The most important achievement of the Second Vatican Council concerning biblical issues is the Dogmatic Constitution on Divine Revelation Dei Verbum, promulgated during the penultimate session on 18 November 1965. The works on the Constitution went on for the whole period of the conciliar proceedings. They started during the first conciliar session on 14 November 1962. The Theological Commission prepared a Schema entitled De fontibus Revelationis. The works on the Schema were supervised by Cardinal A. Ottaviani. Other Commissions assisted in the process. The Schema consisted of five chapters:

I. Two Sources of Revelation

II. Inspiration, Inerrancy and Biblical Genres

III. The Old Testament

IV. The New Testament

V. Sacred Scripture and the Church

Since Cardinal A. Ottaviani's eyesight was poor, during the session on 14 November 1962 the Schema was read by the biblicist, then wellknown in Rome, S. Garofalo. The atmosphere surrounding the works on the Sacred Scripture was so tense that heated discussions were still very common. Some theologians even tried to prepare their own schema projects, which, however, were never officially presented or discussed.

After the first Schema reading the majority of Council Fathers savaged the text, which was thought to be far too conservative. Among the Cardinals who were very critical towards the text's conservative form there were: Cardinal J. Frings from Cologne, P. E. Léger from Montreal, F. König from Vienna, A. Bea from Rome and many others. Among the supporters there were: E. Ruffini from Palermo, G. Siri from Genoa and F. Quiroga y Palacios from Santiago de Compostela. ${ }^{12}$

The disputes showed numerous discrepancies and divisions among the Council Fathers. Further discussions were attempted, but they did not lead to any kind of compromise, quite the contrary, they revealed even greater differences of opinions. It was quite clear that some bishops were in favour of the conservative and careful approach to research on the Sacred Scripture, and, as a result, aimed at preserving the hitherto

${ }^{12}$ Cf. E. Dąbrowski, Sobór Watykański II a biblistyka katolicka, p. 114-115. 
achievements in the field of theology and Biblical Studies. Others opted for greater freedom and development in research on the Bible, advocating the application of the recent historical and archaeological discoveries into the works on biblical texts analysis, and supporting the investigation of literary genres and forms used in the Bible. On 20 November 1962 the voting was held. 1368 bishops voted against the Schema, 822 wanted to continue working on the prepared document. About 100 more votes were needed to reject the Schema, so the works on it continued. A mixed commission was appointed. Its works were supervised by Cardinal A. Ottawiani and Cardinal A. Bea. Two months later the commission agreed on all issues, except for the problem of the relationship between the Sacred Scripture and Tradition and vice versa. ${ }^{13}$

One of the basic arguments against the Schema was the fact that, although the title clearly stated that it was the Schema on Divine Revelation, this particular issue was not addressed. The Fathers pointed out that there was no need to determine this relationship. Moreover, it was noticed that the Schema did not discuss the question of inspiration enough, as it mostly repeated the statements included in the Encyclical of Leon XIII Providentissimus Deus. The inerrancy of the Sacred Scripture and its extent were not determined either.

\subsection{Pilgrimage of Pope Paul VI to the Holy Land}

The Second Vatican Council, especially the part concerning biblical issues, was of great importance for the organisation of Pope's Pilgrimage to the Holy Land from 4 to 6 January 1964. In the speech closing the second conciliar session the Pope specified the aim of his trip and his wish to personally relive the most important mysteries of salvation, to invite those who were disconnected from the Church and to offer His Church to Christ in the place where He Himself was born and died, and having risen from the dead, ascended to Heaven, asking Him to keep the peace. ${ }^{14}$

${ }^{13}$ Cf. A. Wenger, Vatican II. Première Session (L'Eglise en son temps), Paris 1963, p. 116-117.

${ }^{14}$ Cf. E. Dąbrowski, Sobór Watykański II a biblistyka katolicka, p. 139. 
It is noteworthy that the situation in the Holy Land was very complicated at that time. In 1948 the State of Israel was re-established and it was in the state of war with Jordan. The most important for all Christians holy places in Jerusalem and Bethlehem were located in Jordan. Galilee, however, was located in Israel. Considering the terribly complicated political situation of this area, the Pope distanced himself completely from all kinds of political issues, giving his Pilgrimage a purely religious character.

The Pope's Pilgrimage began in Amman, where the Pope landed with his companions. Then he could relive the experience of the Chosen Nation entering the Promised Land by crossing the River Jordan. It is also the place of John the Baptist's activity. The Holy Father visited Jericho, and then, crossing the Judaean Desert, he went to Bethany. He stayed in the building of the Apostolic Delegation, located right next to the Mount of Olives, which made it possible for him to visit different Christian sanctuaries situated on the Mount of Olives. He participated in the Way of the Cross and prayed in the Church of the Holy Sepulchre.

The next part of the Pilgrimage led him through the territory of Israel. The president of Israel welcomed the Pope in Tel Megiddo. From there the Holy Father went to Nazareth, and then to Capernaum, having passed Tiberias, Tabgha and the Mount of Beatitudes. On the next day the Pope participated in the cruise on the Sea of Galilee. The next stage of his Pilgrimage was Mount Tabor, and, after his return to Jerusalem, the Pope visited the Cenacle, which was then located within the borders of Israel.

On 6 January 1964 pope Paul VI visited Bethlehem. Having returned to his residence on the Mount of Olives, he met with Patriarch Anthenagoras I of Constantinopole, as one of the aims of his Pilgrimage was bringing different fractions of Christianity closer. The two meetings with Patriarch Anthenagoras took place on 5 and 6 January 1964. They were of paramount importance for the proceedings of the Second Vatican Council, the character of which became more ecumenical and tightened the relations between the Western and the Eastern Churches.

The Pilgrimage of Paul VI revealed the need of getting to know the Holy Land, its history and archaeology, in the research on the Sacred Scripture. It also emphasised the fact that the care about the Catholic faith must be expressed by the care about the unity of the Church. It is 
therefore worth the efforts of all Christian biblicists to try to find the scientific truth included in the Sacred Books.

\subsection{Tasks of Catholic Exegetes in the Light of the} Instruction of the Pontifical Biblical Commission On the Historical Truth of the Gospels Sancta Mater Ecclesia

On 21 April 1964 the Pontifical Biblical Commission published the Instruction in which it presented the tasks and the mission of the exegetes who decide to do research on the text of the Gospel. The document was published in response to undermining the value of historical data in the Gospel, as well as impairing the authenticity of the words and teachings of Jesus, which were claimed to be coming not from Christ Himself, but from biblical authors, who freely interpreted and quoted them.

The Pontifical Biblical Commission commented on the difficult work of exegetes with great respect, emphasising their effort in looking for scientific truths included in the Sacred Scripture. The document pointed out the need of achieving proficiency in Greek and the application of the newest achievements of the historical-critical method in their research on biblical texts. All biblicists were urged to reach for the results of research done by the Church Fathers, and take care to stay faithful to the truth and the Church while conducting their analysis. ${ }^{15}$

The Instruction was published due to the fact that many Catholic biblicists more and more often reached for the research method created by Protestants, referred to in German as Formgeschichte - the form criticism method. Its developers, namely M. Dibelius, ${ }^{16}$ K. L. Schmidt ${ }^{17}$

${ }^{15}$ Cf. Instructio De historica Evangeliorum veritate, [in:] Enchiridion Biblicum, no. 646.

${ }^{16}$ M. Dibelius (1883-1947) published his theories concerning the origins of the Gospel in the book entitled: Die Formgeschichte des Evangelimus, Tübingen 1919.

${ }^{17}$ K. L. Schmidt (1891-1956) in his work: Der Rahmen der Geschichte Jesu. Literarkritische Untersuchungen zur ältesten Jesusüberlieferung, Berlin 1919, indicated that neither the place of events, nor their chronology should be taken into consideration in the Gospels, as they are all random. 
and R. Bultmann ${ }^{18}$ among others, came to far-reaching conclusions. They claimed that the New Testament Gospels should be classified as the so-called small literature, which meant that they were a disorderly collection of smaller literary forms, created by the Christian community. The primary Christian community consisted of small groups of Jesus' disciples, which began gathering after his death and reminiscing about the events connected with his life and activity. The more years had passed since his death, the more legendary the stories referring to those events became. The task of exegetes, according to Bultmann's method of smaller literary forms analysis, is demythologizing the Gospel. However, they were Bultmann's students who pointed out that the Gospels were written with much thought and were addressed to particular Christian communities. Before the Redaktionsgeschichte method developed, the Catholic exegesis faced a huge challenge of how to defend the historical truth in the Gospels, as well as the authenticity of the words of Jesus and His teaching. It is no surprise that Catholic exegesis was reluctant to use the method and scholarly achievements of R. Bultmann, since his analysis led to the conclusion that the Gospels had no historical value and could only present the Christ of faith, and claimed that our knowledge about historical Jesus was restricted to the fact that he had existed. ${ }^{19}$ Accepting this theory was out of the question, which is why the Conciliar Fathers paid so much attention to the analysis of the Sacred Scripture.

\subsection{Schema De divina Revelatione}

After the first conciliar session on 21 November 1962 Pope John XXIII stopped the discussions on the Schema De fontibus Revelationis and appointed a mixed commission, the aim of which was perfecting the Schema's project. The new altered project was entitled De divina Revelatione. It was ready on 21 April 1964. During the second session, however, the project was not under discussion. The Conciliar Fathers presented their com-

${ }^{18}$ R. Bultmann, Die Formgeschichtliche Methode. Eine Darstellung und Kritik, Giessen 1924.

${ }^{19}$ Cf. R. Bultmann, Jesus, Berlin 1951, p. 11. 
ments and opinions, which were then taken into consideration. On 30 September 1964, with the beginning of the third conciliar session, the project was discussed. The discussion lasted for a week. Other imperfections were found and corrected. The new Schema was not a fierce point of dispute. It consisted of the following chapters:

I. Revelation Itself

II. Handing on Divine Revelation

III. Sacred Scripture, Its Inspiration and Divine Interpretation

IV. The Old Testament

V. The New Testament

VI. Sacred Scripture in the Life of the Church

During the third session, similarly to the first one, two tendencies emerged. One more conservative, the other opting for alterations in the approach to the question of truths included in the Sacred Scripture. According to Cardinal F. König, for example, some content of the Bible comes from people and the traces of the historical and cultural traditions can easily be detected in them. In such situations God's authority should not be involved with this content. ${ }^{20}$

On 6 October all discussions concerning the Schema were finished, and it was sent back to the Commission in order for the last changes to be introduced. A year later, during the fourth session, after all the changes, corrections and modifications had been made, the project was put to the vote between the 20 and 22 September 1965. Almost every single paragraph was voted on separately. There were still too many votes against some of them.

Due to this lack of unanimity, Pope Paul VI intervened personally. He met with Cardinals moderators of the commission working on the project. One of them put and presented his comments in writing. Next, the Pope met with other Conciliar Fathers, and also with theologians. The works on the project were finally going at a faster rate. Commissions and sub-commissions gathered. Discussions were held, changes in the project were implemented. The so-called 'truth' in the Bible proved to be the most controversial. Does it concern all the events included in the

${ }^{20}$ Cf. E. Dąbrowski, Sobór Watykański II a biblistyka katolicka, p. 218. 
Bible, or only the issue of the truth of salvation (veritas salutaris)? Similar concerns were raised in connection with the Gospels, especially with the issue of the historical truth they contained. Do they contain historical data, or are they chronicles of events concerning the life and activity of Jesus Christ? Finally, on 29 October 1965 the Schema was adopted and the Dogmatic Constitution on Divine Revelation Dei Verbum was approved. Pope Paul VI proclaimed it during the ceremonial sitting of the Council on 18 November 1965. That is when the final voting also took place in which 2344 out of 2350 Fathers voted for the Constitution, only 6 were against. $^{21}$

The most important issue that this document, prepared with so much effort, clarifies is the Catholic teaching concerning Divine Revelation. It specifies what Divine Revelation is. ${ }^{22}$ The document states: "In His goodness and wisdom God chose to reveal Himself and to make known to us the hidden purpose of His will" (Dei Verbum, no. 2).

\subsection{Trial of Christ and Declaration Nostra Aetate}

Another important issue that was discussed during the Second Vatican Council was the Catholic Church's approach to the question of responsibility for the trial of Christ, and, as a consequence, taking a stand on the inter-religious dialogue between Christianity and Judaism.

From the very beginning of Christianity the problem of responsibility for sentencing Jesus to death was discussed upon. There are three different standpoints on that matter:

1. Sanhedrin was fully responsible

2. Lay the blame on Pontius Pilate

3. The trial of Jesus took place before the Sanhedrin and the Roman Governor only approved and executed their sentence.

${ }^{21}$ Cf. S. Grzybek, Rys historyczny Konstytucji Dei Verbum, [in:] Idee przewodnie soborowej Konstytucji o Bożym Objawieniu, Kraków 1968, p. 30.

${ }^{22}$ Cf. K. Wojtyła, Znaczenie Konstytucji Dei Verbum w teologii, [in:]: Idee przewodnie soborowej Konstytucji o Bożym Objawieniu, Kraków 1968, p. 9. 
The discussion began as a result of the recommendation of Pope John XXIII, who wanted, once and for all, preclude the possibility of persecuting nations for religious reasons. National socialism in Germany often referred to holding all Jews responsible for the death of Christ. In the name of this responsibility the Jewish nation was persecuted and murdered.

In the Declaration the Conciliar Fathers expressed the view that although Sanhedrin condemned Jesus to death and pressed for execution handing Him over to Pilate, the biblical texts of St. Peter and St. Paul completely exclude the assertion that all Jews are a nation rejected by God. The Declaration states: "Although the Church is the new people of God, the Jews should not be presented as rejected or accursed by God, as if this followed from the Holy Scriptures."23

\section{Conclusions}

The Second Vatican Council took up a very difficult question: how should the truth included in the Sacred Scripture be understood? The Constitution on Divine Revelation Dei Verbum showed that the truth most importantly concerns the question of salvation. Other issues are not crucial for the message of Divine Revelation. They may be concordant with the truth, but they are not essential for the Divine Revelation.

An important event during the Second Vatican Council was the proclamation of the Instruction of the Pontifical Biblical Commission Sancta Mater Ecclesia. Its achievements concern three important issues. The Encyclical of Pius XII Divino afflante Spiritu in exegesis of the Old Testament emphasised the need of taking literary forms in the Bible into consideration. The Instruction pointed out that the rule applied to the New Testament as well, including the Gospels. Morover, Sancta Mater Ecclesiae instructed that the application of literary criticism of the text is an important starting point in its exegesis. The third achievement was the approval of some elements of the Formgeschichte method in research

${ }^{23}$ Enchiridion Biblicum, no. 666. 
on biblical texts, with the exclusion of its incorrect philosophical and theological presuppositions. ${ }^{24}$

The Second Vatican Council opened the door for Biblical Studies, making it possible to take advantage of all available scholarly achievements in the wide range of research on the Sacred Scripture.

Kraków

KS. ROMAN BOGACZ

\section{Summary}

\section{Second Vatican Council Fathers and Their}

Concern about Catholic Biblical Studies

The article presents the significant development of theological and biblical thinking since the beginning of the $20^{\text {th }}$ century until the end of the Second Vatican Council. The tension between natural sciences and Biblical Studies, and thenceforth between historical studies and the matter of historical truth in the Bible, became the cause of numerous disputes, and controversies that Catholic theologians could not manage. Additional difficulties were caused by dubious conclusions of the Protestant exegetes, who stated that based on the Gospels there is only one reliable fact about the historical Jesus - the fact that he had existed (R. Bultmann). The very systematic and persistent work of the Council Fathers led to the formulation of the Dogmatic Constitution on Divine Revelation Dei Verbum. This document described the nature of Divine Revelation and acknowledged all scientific research of the Catholic theologians and biblical scholars.

\section{Keywords}

The Second Vatican Council, biblical studies

${ }^{24}$ Cf. E. Dąbrowski, Sobór Watykański II a biblistyka katolicka, p. 272. 


\section{Streszczenie}

\section{Troska Ojców Soboru Watykańskiego II o biblistykę katolicką}

Artykuł ukazuje znaczny rozwój myślenia teologicznego i biblijnego na przestrzeni od początku XX wieku aż do zakończenia obrad Soboru Watykańskiego II. Zaistniałe napięcia pomiędzy naukami przyrodniczymi a biblistyką, a następnie pomiędzy naukami historycznymi a kwestią prawdy historycznej zawartej w Biblii stały się powodem licznych sporów i trudności, z którymi teologowie katoliccy nie umieli sobie poradzić. Dodatkowo trudności stawały się jeszcze bardziej nabrzmiałe z powodu zbyt daleko idących wniosków wyciąganych przez egzegetów protestanckich, stwierdzających między innymi, że na podstawie Ewangelii nic więcej nie można powiedzieć o Jezusie historycznym jak tylko tyle, że istniał (R. Bultmann). Bardzo systematyczna i wytrwała praca Ojców Soboru doprowadziła do sformułowania Konstytucji Dogmatycznej o Objawieniu Bożym Dei Verbum. Dokument ten przede wszystkim ukazał, na czym polega Boże Objawienie, a także otworzył szeroko drzwi dla wszelkich naukowych badań prowadzonych przez biblistów i teologów katolickich.

\section{Słowa kluczowe}

Sobór Watykański II, biblistyka 
